\title{
KITABIYAT
}

\section{Ayhan Yüksel, Kuğuoğulları, Eski Bir Osmanlı Âyan Ailesi, 1. Baskı, Serander Yayınları, İstanbul, 2017, 299 sayfa, ISBN: 978- 605-66757-5-1}

\author{
Ayhan Yuksel, Kuguogulları, An Old Landowner Ottoman \\ Family, $1^{\text {st }}$ Edition, Serander Publications, Istanbul, 2017, 299 \\ page, ISBN: 978-605-66757-5-1
}

\section{Mevlüt KAYA*}

Geliş Tarihi/Received Date: 24.01.2018-Kabul Tarihi/Accepted Date: 10.07.2018

Doi: 10.30913/alinterisosbil.383343

\begin{abstract}
Atıf Künyesi: Kaya, Mevlüt, “Ayhan Yüksel, Kuğuoğulları, Eski Bir Osmanlı Âyan Ailesi, 1. Bask1, Serander Yayınları, İstanbul, 2017, 299 sayfa, ISBN: 978-605-667575-1", Alinteri Sosyal Bilimler Dergisi (ASOBID), C. 2, S. 3, 2018, ss. 145-148.
\end{abstract}

Osmanlı Devleti'nde yaşadıkları bölgelerde nüfuz kazanmış, devletin gerilemesiyle birlikte yönetimde etkili olmuş aileler çoktur. Ayan olarak adlandirılan bu ailelerin bölgelerindeki etkileri halâ da devam etmektedir. Ayhan Yüksel'in çalışması Kuğuzadeler ailesini tarihi süreçteki rollerini ortaya koyması bakımından önemli bir eserdir.

Osmanlı Devleti'nde 16. yüzyıldan itibaren bozulmaya başlayan toprak sistemi, kent ve kasabalarda âyanların ortaya çıkmasına ortam hazırlamıştır. Toplumun nüfuzlu kişileri olan ve zaman ilerledikçe bulundukları bölgelerde saygınlığı artan âyanlar, devletin toprak ve vergi sisteminin önemli bir unsuru haline gelmişlerdir. Devlet ile toplum arasında aracı bir sınıf konumunda olan âyanların, bölgelerinde önemli idari ve askeri işlevleri olmuştur. Osmanlı Devleti'nin idari, askeri ve sosyoekonomik tarihi açısından önem arz eden âyan ailelerinden biri de Görele'de yaşamış ve Doğu Karadeniz Bölgesi’nde nüfuzuyla etkin olmuş Kuğuzadeler'dir.

Giresun ve Doğu Karadeniz Bölgesi'ne dair araştırmaları neticesinde birçok eser veren Ayhan Yüksel, bu eserinde (Yüksel, 2017) bölgenin âyan ailelerinden biri olan Kuğuzadeler'i incelemiştir. 299 sayfa ve üç bölümden oluşan eserde, Kuğuzade ailesi mensubu olan şahsiyetler hakkında tarihsel bilgiler aktarılmıştır. Ailenin en meşhurlarından Kuğu İbrahim Ağa'nın oğlu, III. Selim'in huzuruna çıkmış ve Trabzon Beylerbeyliği yapmış olan Süleyman Paşa'ya kitabın 42.-73. sayfaları arasında yer verilmiştir. Osmanlı âyanlarından olan bu aile, Cumhuriyet döneminde de etkin görevlerde bulunmuştur. Süleyman Paşa'nın torunu olan Miralay Ali Rıza Kuğu, Balkan

* Öğretim Görevlisi, Giresun Üniversitesi Eynesil Kamil Nalbant Meslek Yüksekokulu, tarihmeltemi@hotmail.com 


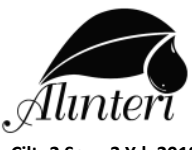

Cilt: 2 Sayı: 3 Yıl: 2018

ss. $145-148$

ISSN: 2564-6583

E-ISSN: 2602-229X

Savaşı gazisidir. Futbol adamı Mehmet Rıza Kuğu ise Trabzon İdman Ocağı kulübünün kurucuları arasında yer almış olan "Kaptan Rıza"dır (Yüksel, 2017; 160-162).

Kitabın giriş kısmında konunun geneline dair bilgiler verilmiş, ardından âyanlığın tarihsel gelişimi işlenmiştir. Birinci bölümde Kuğuzade ailesinin kökenlerine ve ailenin bilinen ilk şahsiyetlerine yönelik bilgiler aktarılmıştır. Ayrıca ailenin Çanakçı yöresinde yerleşen kolu hakkında bilgi verilmiştir (Yüksel, 2017; 23-112). Eserin birinci bölümünde yer verilen şahsiyetler şunlardır: "Ailenin atası" olarak kabul edilen Kuğu İbrahim Ağa, Beylerbeyi Süleyman Paşa (tereke ve borç kayıtlarıyla), haznedar Kuğuzade Hüseyin Ağa, Kuğuzade Osman Bey ve Ömer Beyler, Faş Muhafızı Mehmed Bey, Faş Kalesi muhafızı Rüstem Bey; âyanlar döneminde yaşamış Kuğuzade Emin Bey, Kuğuzade Ali Bey, Kuğuzade Ali Bey oğlu Emin Bey, Kuğuzade Süleyman Bey (Yüksel, 2017; 38-108).

İkinci bölümde, Kuğuzade ailesine dair mahkeme kayıtları incelenmiştir. Evlilik, nikâh ve mahkeme şahitlikleri ve aile fertlerinin sosyal yaşantısı, Kuğuzadeler'e dair başvurulan arşiv kayıtları arasındadır (Yüksel, 2017; 113-158). Kitabın son kısmını teşkil eden üçüncü bölümde ise Kuğuzade ailesinden yetişmiş ve çeşitli branşlarda ülke çapında tanınmış şahsiyetlere yer verilmiştir. Bu şahsiyetlerin içinde 19. yüzyıl sonlarında Galata Gümrüğü kâtipliği yapmış olan Mehmed Hüsnü Bey, Sicil-i Osmanî adlı eseriyle tanınmış olan Osmanlı tarih ve biyografi uzmanı Mehmed Süreyya Bey, Miralay Ali Rıza Bey, meclis-i umum azası Rıza Bey, futbol adamı ve bürokrat Mehmet Rıza Kuğu, 1924 Paris Olimpiyatları katılımcısı Süleyman Rıza Kuğu, Mimar Feyyaz Kuğu, bürokrat Ragıp Kuğu, E. Kur. Alb. İdris Kuğuoğlu, şehit J. Kd. Yzb. Temel Kuğuoğlu, Öğr. Üyesi İbrahim Hayri Kuğuoğlu ve E. General Ali Rıza Kuğu bulunmaktadır (Yüksel, 2017; 158-169).

Eserin sonuç bölümünde, yöre tarihine ve Kuğuzadeler'e yönelik genel bir değerlendirme yapılmış, ardından geniş bir ekler kısmı esere dâhil edilmiştir (Yüksel, 2017; 169-253). Bu kısımda aileye dair Başbakanlık Osmanlı Arşivi'nden edinilmiş belgelerin yanı sıra, Şakir Şevket'in "Trabzon Tarihi”" (Şevket, 2001) adlı eserinde yer verdiği "Süleyman Paşa'nın Tercüme-i Hâli", Trabzon Bidâyet Mahkemesi kayıtları, ailenin Tirebolu'daki kolunu gösteren çizim, aileye dair çeşitli eski fotoğraflar ve mezar taşları bulunmaktadır. Ekler kısmının bu denli geniş olması, eseri ve aydınlattığ1 dönemi anlamada büyük kolaylık sağlamaktadır. Eserin görsellerle desteklenmesi eseri akıcı ve anlaşılır kılmıştır. Ayrıca eserin sonunda sözlük ve dizin kısmının bulunmasının, eser içindeki belge, olay ve ifadelerin her kesimden okuyucunun işini kolaylaştırdığını da belirtmek gerekir. 


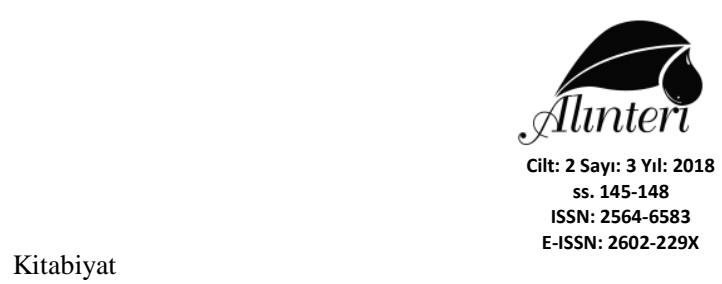

Eserde, arşiv kayıtlarının yanı sıra yıllıklar, sözlü kaynaklar ve aileye ait özel notlarla bazı evraklardan da yararlanılmıştır. Trabzon-Görele arasında yaşanmış pek çok önemli tarihsel olayın ve yörenin geçmişteki sosyal yaşamının daha iyi anlaşılacağı, uzun bir döneme tanıklık etmiş bu eser, Türkiye tarihine önemli katkılar sağlayacak düzeydedir (Yüksel, 2017; 255299). 
Iintere

Cilt: 2 Sayı: 3 Yıl: 2018

ss. $145-148$

ISSN: 2564-6583

E-ISSN: 2602-229X

\section{Mevlüt KAYA}

\section{KAYNAKÇA}

Şevket, Şakir. Trabzon Tarihi, (Haz. İsmail Hacıfettahoğlu), Atlas Yayınları, Ankara 2001.

Yüksel, Ayhan. Kuğuoğulları, Eski Bir Osmanlı Ayan Ailesi, Serander Yayınları, Trabzon 2017. 